\title{
Kimya Öğretmeni Adaylarının “Aziz Sancar'ın Başarısı” Adlı Okuma Parçasındaki Değerler ve Değerler Eğitimine Yönelik Görüşleri*
}

Opinions of Chemistry Teacher Candidates about the Values and Values Education in the Reading Piece Named Aziz

Sancar's Success*

Hatice KARAER, Sorumlu Yazar. Dr. Öğr. Üyesi

Ondokuz Mayıs Üniversitesi, Eğitim Fakültesi, Matematik Fen Bilimleri Eğitimi Bölümü, Kimya Eğitimi A.B.D.

E-mail: hkaraer@omu.edu.tr

ORCID: 0000-0001-7745-9587

Fergan KARAER, Dr. Öğr. Üyesi.

Ondokuz Mayıs Üniversitesi, Eğitim Fakültesi, Matematik Fen Bilimleri Eğitimi Bölümü, Fen Bilgisi Eğitimi A.B.D.

E-mail: fkaraer@omu.edu.tr

ORGID: 0000-0003-3781-2128

\begin{tabular}{|c|c|}
\hline & Atıf/Citation: Karaer, H. \& Karaer, F. (2019). \\
\hline & Kimya öğretmeni adaylarının "Aziz Sancar'ın \\
\hline ISSN: 1303-880X & Başarısı" adlı okuma parçasındaki değerler ve \\
\hline e-ISSN: 2667-7504 & değerler eğitimine yönelik görüşleri. Değerler \\
\hline http://ded.dem.org.tr & Eğitimi Dergisi, 17 (37), 290-316. \\
\hline $\begin{array}{l}\text { Received: } 04.02 .2019 \\
\text { Accepted: } 15.05 .2019 \\
\text { le türü/Article type: }\end{array}$ & $\begin{array}{l}\text { DOI: } 10.34234 / \text { ded.521617 } \\
\text { * Bu çalışma 2. Uluslararası Eğitim Bilimleri ve Sosyal } \\
\text { Bilimler Sempozyumunda sözlü olarak sunulan } \\
\text { bildirinin içerik geliştirilerek ve kısmen değiştirilerek } \\
\text { hazırlanmıştır. }\end{array}$ \\
\hline Araştırma/Research & $\begin{array}{l}\text { * This study is a revised version of the paper presented } \\
\text { at the 2nd International Symposium on Educational } \\
\text { Sciences and Social Sciences. }\end{array}$ \\
\hline
\end{tabular}


Öz: Bu araştırma, öğretmen adaylarının 9. Sınıf Kimya Ders Kitabında yer alan “Aziz Sancar'ın Başarısı” adlı okuma parçasındaki değerler ve değerler eğitimine yönelik görüşlerini belirlemek amacıyla yapılmıştır. Bu amaçla, nitel araştırma desenlerinden fenomenoloji deseni ve bu desene uygun ölçüt örnekleme kullanılmıştır. Araştırmanın katılımcıları, ülkemizdeki bir devlet üniversitesinin eğitim fakültesinin kimya öğretmenliği programında seçmeli ders olarak okutulan "Ortaöğretim Kimya Müfredatı" dersine kayıtllı sekiz gönüllü adaydan oluşmaktadır. Veriler, açık uçlu üç soru içeren görüş formundan, araştırmacılar tarafından yapılan nitel gözlemlerden, kimya öğretim programından ve ders kitabındaki okuma parçasından doküman inceleme tekniğiyle toplanmış ve içerik analiziyle analiz edilmiştir. Elde edilen bulgulardan, değerler ve değerler eğitiminin programlarının odağına yerleştirilmesinde yakın zamanda gerçekleşen 15 Temmuz Kalkışma Hareketinin etkisinin olduğu, değerlerin birkaç ders kapsamında kazandırılmasının yeterli olmayacağı, ailede başlayan eğitiminin okullarda devam etmesi, derslerin kazanımları verilirken değerlerin de kazandırılması ve kalıcılığının sağlanması gerektiği belirlenmiştir. Adayların okuma parçasından belirledikleri değerlerle kimya öğretim programında kazandırılmas1 hedeflenen değerlerin benzerlik gösterdiği ve parçada değerlerin eğitimine atıf yapan ifadelerin bulunduğu saptanmıştır. Aziz Sancar vb. önemli tanınmış şahsiyetlere öğretim programı ve ders kitaplarında daha çok yer verilmesi, değerlerin eğitiminde kullanılan atasözleri vb. diğer araçlardan yararlanılması, hizmet içi eğitimler düzenlenerek öğretmenlerin bilinçlendirilmesi ve kredisiz zorunlu ders olarak lisans programlarında okutulması için gerekli alt yapı çalışmalarının yapılması önerilmektedir.

Anahtar Kelimeler: Aziz Sancar, Değerler, Değerler eğitimi, Kimya ders kitab1, Öğretmen aday1.

$\&$

Abstract: In this study, aimes to determine the opinions of chemistry teacher candidates about the values and values education through the reading passage that titled as "Aziz Sancar's Success" in the 9th grade chemistry textbook. The phenomenology research method was preferred, because the participants of this research were looking at the reading passage (Aziz Sancar's Success) in terms of values and values education, and what kind of perception they formed and the way these perceptions are structured will be analysed. The participants of the research consist of eight chemistry teacher candidates who are enrolled in 'secondary chemistry education' in a state university in Turkey. The data of the 
research was collected by document review from, the form contains open-ended three questions related to; the $9^{\text {th }}$ grade chemistry textbook, the secondary school chemistry curriculum and qualitative observation. In the analysis of the data, content analysis was used. Some noteworthy factors according to teacher candidates necessitate placing the data collected in the research at the centre of values education were; the 15 July coup attempt, the difficulty to transfer values through few courses, having enduring values education that starts at home and continues in schools, along with the skill taught in the subject matter, values acquisition should be included and enhanced. Also, the values the candidates referred to in the reading passage were similar to those in the chemistry curriculum. Prominent figures such as Aziz Sancar should be given more place in textbooks. Benefiting from other tools such as (Proverbs etc. ) in values education is important. In-service trainings should be organized to raise awareness among teachers candidates and finally values education should be taught in undergraduate programs as non-credit mandatory course.

Keywords: Aziz Sancar, values, Values education, Secondary chemistry, Chemistry textbook, Teacher candidate.

\section{Giriş}

Toplumun veya sosyal bir grubun varlığını, birliğini, işleyişini ve devamını sürdürebilmesi için bireylerinin çoğunluğunun doğru, gerekli ve kabul gördükleri ortak duygularını, düşüncelerini, amaçlarını, menfaatlerini yansıtan genelleştirilmiş ahlaki ilkeler veya inançların tümü değer olarak tanımlanmaktadır (Genç ve Eryaman, 2007; Kızılçelik ve Erjem 1994). Değerler; insana yol gösteren, soyut ve nesnelliği bulunmayan, istenilen ve belli bir duruma özgü olmayan, duyguyla ilişkili öznel inançların temsil edildiği tüm durumları içeren hedeflerdir (Özcan, 2017).

Bugünkü eğitim sisteminde, her öğrencinin uygun ahlaki özellikleri davranışlarında gösterecek şekilde yetişmeleri amaçlandığından öğrencileri sadece akademik açıdan başarılı bireyler olarak değil aksine değerlerini bilen ve onları davranışlarında gösteren bireyler olarak yetiştirilmeleri beklenmektir. Bu amaç doğrultusunda Millî Eğitim Bakanlığı (MEB), tüm öğretim programlarına kök değerleri ilave ettiği gibi odağına yerleştirmiştir (MEB, 2017). Yeni öğretim programları ile önceki öğretim programları karşılaştırıldığında içerik açısından bazı farklılıklar olsa da asıl önemli fark önceki programların merkezinde öğrencilere "beceri kazandırmak" varken yeni programların merkezinde "milli ve 
manevi değerleri kazandırmak" yer almaktadır (Coşkun, 2016-2017). Demirel (2009), son yıllarda Türkiye'de değerlerin öğretim programlarında olduğunu, birçok okulda değerler eğitimiyle ilgili yeni projelerin başlatıldığını, sosyal bilgiler dersi öğretim programında toplumsal konularda değerler ve değerler eğitimi doğrudan vurgulanırken diğer derslerde dolaylı olarak yer aldığını belirtmiş̧tir. MEB'in 3 Ocak-10 Şubat 2017 tarihleri arasında yayınladığı metne göre öğretim programlarının yenilenmesi ve güncellenmesinin nedenlerinden birinin milli ve manevi değerlerin öğrencilere kazandırılmasına verilen önemin artırılması olduğu, öğretim programlarında “Değerlerimiz" başlığı altında verildiği ve her dersin içeriğine göre farklılık gösterebileceğini açıklanmıştır (MEB, 2017). Örneğin Türkçe, Tarih vb. derslerdeki değer sayısının Matematik, Fizik, Kimya vb. derslerden daha fazla olması dersin içeriğinden kaynaklandığı belirtilmektedir. Koç ve Çelik (2017), lisansüstü öğrencilerin görüşlerinden hareketle ortaokul öğretim programlarında örtük olarak verilen değerlerin inanç ve demokratik bir görüşle tanımlandığını açıklamışlardır.

Milli Eğitim Temel Kanununda "Türk milletinin milli, ahlaki, insani, manevi ve kültürel değerlerini benimseyen, koruyan ve geliştiren bireyler yetiştirmek" ifadesinin olması tüm öğretim programlarında ortak değerlerin oluşturulmasının kaçınılmaz olduğunu göstermektedir (Tedmem, 2017). Değerler, sadece eğitim alanında değil aynı zamanda gündelik faaliyetlerde de önemlidir (Taylor, 2000; Halstead \& Taylor, 2005). Çünkü değerler eğitimi, öğrencilerin sorumluluk alma ve makul seçimler yapabilme olanaklarıyla ilgili bilgi, beceri ve yeteneklerini geliştirecekleri tüm gayretleridir. Bu tür eğitimle yetişen öğrenciler, küreselleşen çok kültürlü dünyaya uyum sağlayacakları gibi yaşamın gerçekleriyle yüzleşerek eleştirel düşünmelerine ve sorumluluk almalarına da yardımcı olacaktır (Durmuş, 2017). Ailelerin, medyanın, akran grubunun yanı sıra çocukların ve gençlerin dolayısıyla toplumun gelişmesinde önemli rol oynayan okullar aynı zamanda toplumun değerlerini yansıtan ve somutlaştıran kurumlardır (Çelikkaya ve Kürümlüoğlu, 2018; Halstead \& Taylor, 2005; Taylor, 2000). Dilmaç ve Şimşir (2016), okullarda değerler eğitimine yer verilmesi gerektiğini ancak değerler eğitiminin sadece okullara bırakılmasının büyük hata olacağını belirtirken; Cihan (2014), değerlerin öğrencilere kazandırılmasında okul ve aile iş birliğinin sağlanması gerektiği aksi halde öğrencilerin çelişkiler yaşayacağını açıklamıştır. Okullarda öğrencilerin belirli değerleri fark etmeleri, yeni değerleri üretebilmeleri, benimseyebilmeleri ve içselleştirerek davranışlarında göstermeleri için öğretmenlerin yükü ve sorumluğu fazladır (Cihan, 2014; Durmuş, 2017). Balcı ve Yanpar Yelken (2013), öğretmenlerin değerlerin öğ- 
rencilere kazandırılmasında ailelerin, sosyoekonomik ve kültürel yapının öneminin çok fazla olduğunu, değer kazandırmanın en etkili yolun çocuğa değer verildiğinin hissettirilmesinden geçtiğini ifade etmiştir. Ayrıca araştırmacılar değerlerin kazandırılmasında en etkili yöntemin örnek olay, en az etkili olanın geleneksel telkin yöntemi olduğunu belirlemişlerdir. Thronberg (2008 a, b), öğretmenlerin değerler eğitimini uygularken gündelik dili kullanmalarının onların mesleki gelişimlerinde belirgin şekilde engel teşkil ettiğini ve okul kurallarının gündelik gelişimini değerler eğitiminin belirlediğini açıklamıştır. Thornberg ve Oğuz (2013), İsveç ve Türk öğretmenlerin değerler eğitimine bakış açılarının benzer olduğunu, eleştirel bir yaklaşım gösteremediklerini, temel değerler eğitimi yöntemleriyle öğrencilerin günlük etkileşimlerinde iyi bir rol model olduklarını, öğretmenlerin değerleri tanımlarken gündelik bir dil kullandıklarına ve bu alanda bilgi eksikliklerinin bulunduğuna dikkat çekmişlerdir. Ünal (2011), Antalya merkez ilçedeki ortaöğretim okullarında görev yapan ve alanları fizik, kimya, biyoloji matematik, tarih ve coğrafya olan 485 öğretmenin öğrencilerine kazandırmak istedikleri 127 değer olduğunu tespit etmiştir. Araştırmacı bu değerlerden saygı, sevgi, dürüstlük, sorumluluk, bilimsellik, vatan sevgisi, özgüven, ahlaki değerler, çalışkanlık, başarılı olma, iyi insan olma, Atatürkçü düşünce, akılcı olma, çevre bilinci, ülke sorunlarına duyarlılık ve toplum bilinci değerlerinin çoğunlukta olduğunu belirtmiştir. Bunların arasında sevgi, saygı ve dürüstlük değerlerinin ilk sıralarda yer aldığını, bütün öğretmenlerin öğrencilerine sevgi, saygı, dürüstlük, bilimsellik ve sorumluluk değerlerini kazandırmayı tercih ettiklerini açıklamıştır.

Değerlerin öğrencilere kazandırılmasında tarihi olaylar, sosyal etkinlikler, kültürel miras, atasözleri, deyimler, özlü sözler, şarkılar, türküler, şiirler, Nasrettin Hoca fikraları, şahsiyetli kişiler, bilge insanlar ve sorumluluk projeleri vb. araçlar kullanılmaktadır (Karaer ve Avcı, 2018). Yazıcı ve Aslan (2011), değerlerin eğitiminde rol modellerden yararlanmanın etkili bir yöntem olduğunu belirterek kahramanların ders kitaplarında olması gerektiğini belirtmişlerdir. Ayrıca araştırmacılar rol model olacak kahramanların ders kitaplarında olmasının Türk eğitim sisteminin ulusal ve evrensel boyutuna, felsefi temellerine, tarihsel ve sosyolojik belirleyicilerin aydınlatılmasında katkıda bulunacağını ifade etmişlerdir. Faiz ve Yazıcı (2018), öğrencilere değerlerin eğitiminde doğru kahramanların seçilmesi durumunda olumsuz öğrenme ortamlarında dahi değer öğretiminin kolaylaşacağını belirtmişlerdir. Nitekim yeni kimya öğretim programında değerlerin kazandırılmasında kullanılan araçlardan biri Aziz Sancar, Oktay Sinanoğlu, vb. önemli şahsiyetlere ait okuma parçalarıdır (Güntut, Güneş ve Çetin, 2018). 


\section{Araştırmanın Amacı ve Önemi}

$\mathrm{Bu}$ araştırmada kimya öğretmeni adaylarının 9. Sınıf Kimya Ders Kitabında yer alan “Aziz Sancar'ın Başarısı” adlı okuma parçasındaki (Şekil 2) değerler ve değerler eğitimine yönelik görüşlerini belirlemek amacıyla yapılmıştır. $\mathrm{Bu}$ araştırmada ortaöğretim kimya öğretim programı ve ders kitabındaki “Aziz Sancar 'ın Başarısı" adlı okuma parçasının değerler ve değerler eğitimi açısından incelenmesi, Aziz Sancar'ın başarısında değerlerin yerinin ve öneminin açıklanması, değerlerin eğitiminde Aziz Sancar vb. önemli şahsiyetlere ait okuma parçalarının iyi bir araç olduğunu göstermesi bakımından alana katkı sağlayacağ1 düşünülmektedir. Aynı zamanda kimya öğretmeni adaylarına değerler ve değerler eğitimi açısından ders kitabındaki bir okuma parçasının nasıl analiz edileceğine yönelik bilgi, beceri ve deneyimin kazandırıldığını göstermesi " Aziz Sancar 'ın Başarısı" adlı okuma parçasını değerler ve değerler eğitimi açısından inceleyen ilk araştırma olması nedeniyle yapılacak araştırmalara katkı sağlayacağı söylenebilir.

\section{Araştırmanın Problemi ve Alt Problemleri}

Araştırmanın problemi, öğretmen adaylarının 9. Sınıf Kimya Ders Kitabında yer alan “Aziz Sancar'ın Başarısı” adlı okuma parçasındaki değerler ve değerler eğitimine yönelik görüş ve düşünceleri nelerdir?

Bu problem kapsamında belirlenen altı alt problem aşağıda verilmiştir:

1. Öğretmen adaylarının görüşlerine göre ortaöğretim kimya öğretim programinda hangi değerler bulunmaktadır?

2. Öğretmen adaylarının görüşlerine göre ortaöğretim kimya öğretim programina değerler neden ilave edilmiştir?

3. Öğretmen adaylarının görüşlerine göre ortaöğretim kimya öğretim programındaki değerler öğrencilere neden kazandırılmak istenmiştir?

4. Öğretmen adaylarının görüşlerine göre ortaöğretim kimya öğretim programındaki değerler öğrencilere nasıl kazandırılabilir?

5. Öğretmen adaylarının görüşlerine göre “Aziz Sancar'ın Başarısı” adlı okuma parçasında hangi değerler bulunmaktadır?

6. Öğretmen adaylarının görüşlerine göre "Aziz Sancar ’ın Başarısı” adlı okuma parçasındaki hangi ifadelerle değerler kazandırılabilir? 


\section{Yöntem}

\section{Araştırmanın Deseni}

Araştırmada nitel araştırma desenlerinden fenomenoloji (olgu-bilim) deseni kullanılmıştır. Çünkü bu araştırmanın katılımcıları "Aziz Sancar'ın Başarısı" adlı okuma parçasını değerler ve değerler eğitimi açısından incelerken onlarda ne tür bir algı oluşturduğu ve nasıl yapılandırdıklarının araştırılması hedeflendiği için fenomenoloji deseni tercih edilmiştir. Fenomenoloji günlük hayatla ilgili deneyimleri vurgulu açıklayan ve derinlemesine sistematik olarak araştırma yapılmasına firsat veren öznel bir desendir. Bu desen katılımcıların olgu ya da olaylarla yaşantılarının nasıl olduğu, algılarının neden oluştuğu, duygu ve düşüncelerinin nelerden kaynaklandığını tespit etmek amacıyla kullanılmaktadir (Creswell, 2016; Johnson ve Christensen, 2014; Khan, 2014; Padilla-Diaz, 2015; Yüksel ve Yıldırım, 2015). Fenomenolojide araştırıcıya olgunun içerdiği ortak anlamları ortaya çıkarmadan önce katılımcıların yaşanmış deneyimlerini tanıması ve özünü nelerin oluşturduğunu belirtmesi gerekmektedir (Onat-Kocabiyık, 2016).

\section{Araştırmanın Katılımcıları}

Araştırmada fenomenoloji deseni kullanıldığından amaçlı örnekleme türlerinden kolay uygulanabilir olması, kısa sürede sonuçlandırılması ve araştırmacıya ölçütü kendisinin belirlemesine olanak sağladığı için ölçüt örnekleme tercih edilmiştir. Harsh'a (2011) göre, amaçlı örnekleme alandaki önemli bilgi kaynaklarına ulaşmak için araştırmacıya yardımcı olmaktadır. Patton'a (2015) göre, amaçlı örnekleme en yaygın kullanılan örnekleme yöntemi olup derinlemesine araştırma yapmak için olgu ya da olaylarla ilgili bilgisi olan ve belirli özellikleri taşıdığı düşünülen katılımcılardan tercih edilmelidir. Ayrıca araştırmanın amacına uygun olarak örneklem üç ile on kişi arasında olabilmektedir (Creswell, 2016; Gentles, Charles, Ploeg ve McKibben, 2015). Bu yüzden araştırmanın katılımcıları seçilirken ortaöğretim kimya öğretim programlarından, ders kitaplarından, literatürde kimya öğretim programı ve ders kitaplarına yönelik yapılmış araştırmalardan haberdar olan, değerler ve değerler eğitimi hakkında yorum yapabilecek bilgiye sahip olan gönüllü kimya öğretmeni adaylarından olması şeklinde ölçütler aranmıştır. Bu ölçütleri sağlayan araştırmanın katılımcıların1, ülkemizdeki bir devlet üniversitesindeki eğitim fakültesinin 4 yıllık kimya 
öğretmenliği lisans programında seçmeli ders olarak okutulan "Ortaöğretim Kimya Müfredatı" dersine kayıtlı ve gönüllü olan sekiz kimya öğretmeni adayı oluşturmaktadır. Adaylardan biri erkek diğerleri kadın olup biri meslek lisesinin kimya bölümünden diğerleri Anadolu lisesinden mezun olmuşlardır. Öğretmen adaylarının tümü öğretmenlik mesleğini isteyerek seçtiklerini ve bu bölümü okumaktan memnun olduklarını belirtmişlerdir.

\section{Veri Toplama Araçları}

Araştırmanın verileri, açık uçlu üç soru içeren görüş formundan, 9. Sınıf Kimya Ders Kitabında yer alan “Aziz Sancar'ın Başarısı” adlı okuma parçasından ve Ortaöğretim Kimya Öğretim Programından doküman inceleme tekniği ile elde edilmiştir. Ayrıca öğretmen adaylarının okuma parçasını değerler ve değerler eğitimi açısından inceledikleri sırada araştırmacılar tarafından yapılan nitel gözlemlerinden toplanmıştır. Doküman inceleme tekniği, araştırma konusuyla ilgili bilgileri içeren kitap, dergi vb. materyaller olabildiği gibi video, fotoğraf vb. materyaller de olabilmektedir. Doküman analizinde araştırıcılar doküman olarak hangi materyal ya da materyallerin kullanılacağına araştırmanın problemi doğrultusunda karar verdiklerinden bu araştırmada doküman olarak "Aziz Sancar'ın Başarısı" adlı okuma parçası (Şekil 2), A4 kâğıdına fotokopi ile çoğaltılmış ve gönüllü öğretmen adaylarına dağıtılmıştır. Sonra adaylara parçayı dikkatle okumaları, değerler ve değerler eğitimi açısından incelemeleri ve neden öyle düşündüklerini okunaklı şekilde yazarak açılamaları gerektiği belirtilmiştir. Katılımcıların okuma parçasında olduğunu düşündükleri değerlerin öğretim programında bulunup bulunmadığını belirlemek için Ortaöğretim Kimya Öğretim Programında yer alan değerlerle karşılaştırılmıştır. Bu yüzden öğretim programında yer alan "Değerlerimiz" Şekil 1'de; 9. sınıf Kimya Ders Kitabında yer alan "Aziz Sancar'ın Başarısı" adlı okuma parçası Şekil 2'de ve görüş formundaki açık uçlu üç soru Tablo 1'de verilmiştir.

Tablo 1: Görüş Formunda Yer Alan Açık Uçlu Sorular

Sorular

1 Ortaöğretim kimya öğretim programında hangi değerler olabilir ve neden ilave edilmiştir? Neden öyle düşündüğünüzü açıklayınız. Ortaöğretim kimya öğretim programındaki değerler öğrenciye nasıl kazandırılabilir? Neden öyle düşündüğ̈nüzü açıklayınız. 


\section{Verilerin Analizi}

Görüş formundaki öğretmen adayların görüşlerini okuyucunun anlayabileceği duruma getirmek için içerik analizi kullanılmıştır. İçerik analizi, metinlerin incelenmesi sonucunda katılımcıların belirlenen görüşleri veya yorumları, bir dizi aşamalar sonucunda oluşturulan kategoriler, kodlar ve temalarla anlamlı hale getirilmesinde kullanılan bir tekniktir (Rose, Spinks ve Canhoto, 2015; Zhang ve Wildemuth, 2009). Burada önemli olan hangi mesajı kime neyle ulaştırıldığıdır (Weber, 1989, Akt: Koçak ve Arun, 2006). Öğretmen adaylarının görüşlerinin analizinde alt problemler dikkate alınarak temalar belirlenmiştir. Belirlenen temalar uzman öğretim elemanlarına gösterilmiş onların görüş ve önerileri doğrultusunda düzeltmeler yapılarak altı tema oluşturulmuştur. Oluşturulan temalar sırasıyla "Programda bulunan değerler", "Değerlerin programa eklenme nedeni". "Değerlerin kazandırılma nedeni", "Değerlerin kazandırılma şekli”, "Aziz Sancar'ın Başarısı adlı okuma parçasındaki değerler" ve "Aziz Sancar'ın Başarısı aracılı̆̆ ile değ erler ĕgitimi” şeklinde altı temada toplanmıştır.

\section{Geçerlilik ve Güvenilirlik}

Bilimsel nitel araştırmaların en önemli ölçütlerden biri araştırmadan elde edilen sonuçların inandırıcı olmasıdır. Bu amaçla en yaygın kullanılan ölçütler iç ve dış şeklinde ayrı ayrı değerlendirilen geçerlilik ve güvenilirliktir. İç geçerlilik, araştırmacının gözlemleriyle anladığını düşündüğü olgu veya olayları ilişkilendirdiğinde gerçeği yansıtması olarak tanımlanırken; dış geçerlilik, araştırmadan elde edilen sonuçların birbirine benzerlik gösteren ortam ve şartlara göre genelleştirilebilmesidir (Başkale, 2016; Yıldırım ve Şimşek, 2013). Bu araştırmada yer alan öğretmen adaylarına ait bilgilerin araştırmanın katılımcıları bölümünde ayrıntılı şekilde açıklanması, veri toplama araçlarının neden ve nasıl kullanıldığı, “Aziz Sancar'ın Başarısı" adlı okuma parçası A4 kâğıdına fotokopi ile neden çoğaltıldığına yönelik bilgiler verilerin toplanması başlığı altında detaylı şekilde verilmesi araştırmanın iç geçerliliğinin sağlandığını düşündürmektedir. Araştırmanın dış geçerliliğinde neden ölçüt örnekleme ile katılımcılarının seçildiği, ölçüt örnekleme kararının nasıl alındığı, verilerin toplamasında nelerle karşılaşıldığ1 ve analizin nasıl yapıldığ1 hakkında gerekli bilgiler ilgili bölümlerde ayrıntılı şekilde açıklandığı için dış geçerliliğin de sağlandığı düşünülmektedir. Öğretmen adaylarının görüşlerinden hareketle oluşturulan temaların uygun olup olmadığını belirlemek için uzman öğretim elemanlarının görüşlerinin alınması ve onların görüş ve önerileri doğrultusunda düzenlenmesi araştır- 
manın iç güvenilirliğinin sağlandığı söylenebilir. İçerik analizi sonucunda elde edilen bulgularla araştırma sonuçlarının karşılaştırılmasında uzman görüşüne başvurulması ve araştırmacıların araştırmadaki rolünü göstermesi bakımından dış güvenirliğinin de gerçekleştirildiği söylenebilir. Çünkü iç güvenilirlik başka araştırmacıların aynı verileri kullanarak aynı sonuçlara ulaşmasındaki tutarlılık şeklinde tanımlanırken, dış güvenilirlik araştırmada ulaşılan sonuçların birbirine benzeyen ortam ya da şartlarda benzer sonuçlara ulaşmasıyla ilgili teyit edilebilirliğidir (Başkale, 2016; Yıldırım ve Şimşek, 2013).

\subsubsection{Değerlerimiz}

Değerlerimiz öğretim programlarının perspektifini oluşturan ilkeler toplamıdır. Kökleri geleneklerimiz ve dünümüz içinde, gövdesi ve dallanı bu köklerden beslenerek bugünümüze ve yarınlarımıza uzanmaktadır. Temel insani özelliklerimizi oluşturan değerlerimiz, hayatımızın rutin akışında ve karş̧ış̧tığımız sorunlarla başa çıkmada eyleme geçmemizi sağlayan kudretin ve gücün kaynağıdır.

Bir toplumun geleceğinin, değerlerini benimsemiş ve bu değerleri sahip olduğu yetkinliklerle ete kemiğe büründüren insanlarına bağlı olduğu tartışma götürmez bir gerçektir. Bundan dolayı eğitim sistemimiz her bir üyesine uygun ahlaki kararlar alma ve bunları davranışlarında sergileme yeterliliğini kazandırma amacıyla hareket eder. Eğitim sistemi sadece akademik açıdan başarılı, belirlenmiş bazı bilgi, beceri ve davranışları kazandıran bir yapı değildir. Temel değerleri benimsemiş bireyler yetiştirmek asli görevidir; yeni neslin değerlerini, alışkanlıklarını ve davranışlarını etkileyebilmelidir. Eğitim sistemi değerleri kazandırma amacı çerçevesindeki işlevini, öğretim programlarını da kapsayan eğitim programıyla yerine

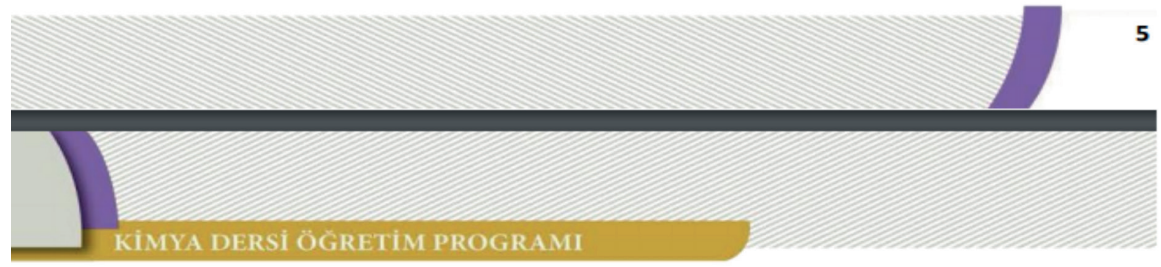

getirir. "Eğitim programı"; öğretim programları, öğrenme öğretme ortamları, eğitim araç gereçleri, ders dışı etkinlikler, mevzuat gibi eğitim sisteminin tüm unsurları göz önünde bulundurularak oluşturulur. Öğretim programlarında bu anlayışla değerlerimiz, ayrı bir program veya öğrenme alanı, ünite, konu vb. olarak görülmemiştir. Tam aksine bütün eğitim sürecinin nihai gayesi ve ruhu olan değerlerimiz, öğretim programlarının her birinde ve her bir biriminde yer almıştır.

Öğretim programlarında yer alan "kök değerler" şunlardır: adalet, dostluk, dürüstlük, öz denetim, sabır, saygı, sevgi, sorumluluk, vatanseverlik, yardımseverlik. Bu değerler, öğrenme öğretme sürecinde hem kendi başlarına, hem ilişkili olduğu alt değerlerle ve hem de öteki kök değerlerle birlikte ele alınarak hayat bulacaktır.

Şekil 1. Ortaöğretim Kimya Öğretim Programında Yer Alan Değerlerimiz 


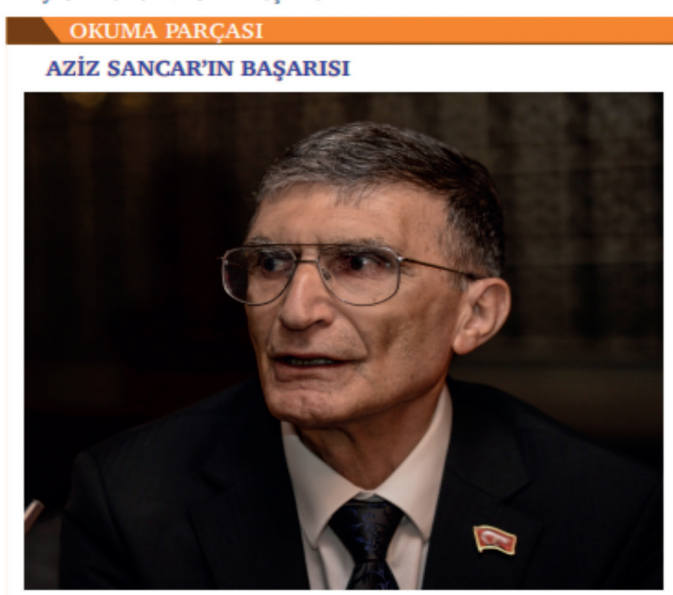

Görsel 3.4.12: Prof. Dr. Aziz SANCAR

Aziz Sancar; 8 Eylül 1946 'da Mardin'in Savur ilçesinde, orta gelirli çiftçi bir ailenin sekiz çocuğundan yedincisi olarak doğmuş; akademisyen, tup doktoru, biyokimyager, moleküler biyolog ve bilim insanıdır (Görsel 3.4.12). Illk eğitimini Mardin'de tamamlayan Sancar, İstanbul Üniversitesi Tıp Fakültesinden 1969 yılında birincilikle mezun oldu. İki yıl Savur'da bir sağlık ocağında doktorluk yaptıktan sonra NATO-TÜBITAK bursu ile Dallas'a giderek Teksas Üniversitesinde Moleküler Biyoloji dalında doktora yaptı. Yale Üniversitesinde DNA onarımı dalında doçentlik tezini tamamlayarak DNA onarımı, hücre dizilimi, kanser tedavisi ve biyolojik saat üzerinde çalışmalarına devam etti.

1997 yllından bugüne ABD'deki Kuzey Carolina Üniversitesi Biyokimya ve Biyofizik Bölümünde görev yapan Prof. Sancar, yayımladığ 33 kitap, 415 bilimsel makale ve bu makalelere yapılan 12 binden fazla atıfla bilim dünyasında az rastlanır bir başarıya imza att. Yaptığı çalıșmalarla Amerikan Ulusal Bilimler Akademisine kabul edilen Sancar, buraya kabul edilen üç Türk'ten biri olmuștur.

Mardin'in Savur ilçesinden ABD'deki kürsü profesörlüğüne götüren yol alınteriyle doludur. İnatla, sabırla, kararlılıkla yoğrulmuş. Yurduna ve büyüdüğü Savur ilçesine son derece bağlı olan Sancar, Savur Lisesi birincisine her yll 7500 dolar ödül veriyor. Bu tutumuyla Savurlu gençleri kendisini izlemeye çağırıyor. Ayrıca Nobel Ödüllü bilim insanı Aziz Sancar, 2008 yılında kendi birikimi olan 1 milyon dolar ile Chapel Hill kasabasında bir ev satın aldı. Buraya Carolina "Türk Evi" adını verdi. Amerikalı eși Gwen ile birlikte ABD'ye doktora için gelen Türk öğrenciler kendi yaşadığı zorluklanı yaşamasın diye evini o çocuklara açtı ve burayı hem yurt hem de kültür merkezi olarak kullanmaya başladı. İlgi duyan Amerikalılar için bir de Türkçe eğitim kursu açtı.

Aziz Sancar hücrelerin hasar gören DNA'ları nasıl onardığını ve genetik bilgisini koruduğunu haritalandıran araştırmaları sayesinde 2015 Nobel Kimya Ödülü'nü kazandı. Ödül töreninde konuşan Sancar: "Ne yaparsanız, iyi yapmaya çalıșın, çalıșmadan olmaz. Öğrenciyken günde 18 saat çalışırdım. Gecelerimi laboratuvarlarda geçirmiş̧imdir. Çalıșmaktan başka çare yoktur. Bu, vatan borcudur" dedi. Prof. Dr. Sancar kendisiyle yapılan bir röportajda özgüvenin önemini vurgulayarak: "Özgüveni bana cumhuriyet verdi, çok idealist hocalarımız vardı. Biz Türkler her șeyi yaparız, her şeyi bașarırız. Biz çalıștığımız ve ürettiğimiz sürece üstün olacağız, üstünlük genetik değildir, bütün insanlar birbirine eșittir. Çoğu insan zekaya inanır, ben inanmıyorum, bizi birbirimizden ayıran emektir, ben çalışmaya inanıyorum." diye konuștu. "Aziz Sancar deyince aklınıza ne geliyor?" sorusuna: "Ben şan ve şöhretle tanınmak istemem. Bana aynı soruyu sorarsanız yanıtım şu olur: "Hayatı boyunca çok ama çok çalıșmıș ve buluşlarıyla insanlığa katkı yapmış bir vatansever. Özellikle çocuklarımızın, şan ve şöhretin sadece olağanüstü çalışmanın bir yan etkisi olduğunu bilmelerini isterim." demiştir. "Nobel almak güzel ama ondan da güzel şey Nobel'i almaya giden yol ve yapılan keșiftir. Beni ödüle götüren Atatürk'ün ve Türkiye Cumhuriyeti'nin yaptığı eğitim devrimidir. Dolayısıyla bu ödülün sahibi Atatürk ve Türkiye Cumhuriyeti’ni temsil eden Anıtkabir Müzesidir" diyerek Nobel Ödülü ile madalya ve sertifikasını Anıtkabir'e teslim etmiştir. Ödül, Anıtkabir'deki Atatürk ve Kurtuluş Savaşı Müzesinde kendisine ayrılan özel alanda sergilenmektedir.

Aziz Sancar ve Nobel'in Öyküsü kitabından yararlanılarak yazarlar tarafindan bu kitap için yazılmştur.

134

Şekil 2. 9. Sınıf Kimya Ders Kitabında Yer Alan "Aziz Sancar'ın Başarısı” Adlı Okuma Parçası

\section{Bulgular}

Araştırmanın amacı doğrultusunda toplanan veriler alt problemler dikkate alınarak analiz edilmiş ve tablolar halinde verilmiştir. 


\section{Birinci Alt Probleme İlişkin Bulgular}

Tablo 2: Öğretmen Adaylarının Kimya Öğretim Programındaki Değerlere Yönelik Görüşlerinin Frekans ve Yüzde Oranları

\begin{tabular}{llll}
\hline Değerler & Katılımcılar & f & \% \\
\hline Vatanseverlik & Ö1, Ö2, Ö3, Ö4, Ö5, Ö6, Ö7, Ö8 & 8 & 100,0 \\
\hline Yardımseverlik & Ö1, Ö2, Ö3, Ö4, Ö5, Ö6, Ö7, Ö8 & 8 & 100,0 \\
\hline Sayg1 & Ö1, Ö2, Ö5, Ö6, Ö7, Ö8 & 6 & 75,0 \\
\hline Sevgi & Ö1, Ö2, Ö5, Ö6, Ö7, Ö8 & 6 & 75,0 \\
\hline Sabır & Ö1, Ö2, Ö5, Ö6, Ö7, Ö8 & 6 & 75,0 \\
\hline Çalı̧̧kan & Ö2, Ö3, Ö6, Ö7, Ö8 & 5 & 62,5 \\
\hline Dostluk & Ö2, Ö3, Ö5, Ö7, Ö8 & 5 & 62,5 \\
\hline Dürüstlük & Ö1, Ö2, Ö3, Ö7, Ö8 & 5 & 62,5 \\
\hline Özdenetim & Ö1, Ö2, Ö6, Ö7, Ö8 & 5 & 62,5 \\
\hline Sorumluluk & Ö1, Ö2, Ö7, Ö8 & 4 & 50,0 \\
\hline Adalet & Ö2, Ö3, Ö7, Ö8 & 4 & 50,0 \\
\hline Minnettarl1k & Ö4, Ö5 & 2 & 25,0 \\
\hline Azmetme & Ö3, Ö4 & 2 & 25,0 \\
\hline Alçak gönü1lülük & Ö6, Ö5 & 1 & 12,5 \\
\hline Dayanışma & Ö4, Ö7 & 1 & 12,5 \\
\hline İdealist & Ö4 & 1 & 12,5 \\
\hline Milli birlik ve beraberlik & Ö5 & 1 & 12,5 \\
\hline Özgürlük & Ö5 & 1 & 12,5 \\
\hline Özgüven & Ö5 & 1 & 12,5 \\
\hline
\end{tabular}

Tablo 2'de öğretmen adaylarının görüşlerinden kimya öğretim programında bulunan değerlerle öğretim programda öğrencilere kazandırılmak istenilen değerlerin arasında benzerlik olduğu belirlenmiştir.

\section{İkinci Alt Probleme İlişkin Bulgular}

Tablo 3: Öğretmen Adaylarının Kimya Dersi Öğretim Programına Değerlerin Eklenme Nedenine Yönelik Görüşleri

\section{Görüşler}

Programın hemen öncesinde 15 Temmuz kalkışma hareketi yaşandığ

Milli birlik ve beraberliğin aşılanması için,

Değerlerin ailede başlayıp okulda devam etmesi gerektiği için,

Öğrencilere okul çağında değerlerin kazandırılması istendiği için,

Kimya bilgisinin yanında ahlaki ve insani değerlerin kazandırılması hedeflendiği için

Öğretmen adaylarının kimya öğretim programına değerlerin eklenme nedenleriyle ilgili görüşlerden (Tablo 3) en dikkati çeken görüşlerin 15 Temmuz kalkışma hareketinin yaşanması ve öğrencilere milli birlik ve beraberliğin kazand1rılmasının istenmesine yönelik görüşlerinin çoğunlukta olduğu tespit edilmiştir. 


\section{Üçüncü Alt Probleme İlişkin Bulgular}

Tablo 4: Öğretmen Adaylarının Görüşlerine Göre Öğrencilere Değerlerin Kazandırılma Nedenleri Görüşler

Öğrencilere ailede başlayan değerler eğitimin okulda da devam ettiğinin gösterilmesi istendiği için,

Milli birlik ve beraberlik, vatanseverlik vb. değerlerin kazandırılması hedeflendiği için,

Sadece sosyal içerikli derslerde değil tüm derslerde verilmesi gerektiği için,

Kimya öğretiminin yanında değerlerin eğitimini alarak ileride vatanını, milletini seven, üretken, çalışkan bireyler olmaları istendiği için,

Öğretmen adaylarının kimya öğretim programına değerlerin kazandırılma nedenlerine yönelik görüşleri (Tablo 4) incelendiğinde değerlerin ailede başladığını, okulda devam etmesi ve tüm derslerde olması gerektiğine yönelik görüşlerin daha çok olduğu belirlenmiştir.

\section{Dördüncü Alt Probleme İlişkin Bulgular}

Tablo 5: Öğretmen Adaylarının Görüşlerine Göre Öğrenciye Değerlerin Kazandırılma Şekli

\section{Görüşler}

Bilim insanlarının hayat hikâyeleri verilerek öğrenciler özendirilebilir.

Kitaplara okuma parçası olarak önemli kişilerle ilgili bilgiler verilebilir.

Öğretmenler ders sırasında yeri geldiğinde konuyla ilişkili olan değerlerden söz edebilir.

Öğrencilere değerleri kazandırmak için öncelikle öğretmenlerin bu konuda bilinçlendirilmesi gerekir.

Bunun için hizmet içi eğitimler düzenlenebilir.

Atatürk'ün hayatına daha çok yer verilebilir.

Öğretmen adaylarının lisans programlarında değerler ve değerler eğitimine yönelik kredisiz zorunlu ders olabilir.

Öğrencileri çeşitli sorumluluk projelerine dâhil edilebilir.

Öğretim programı ve ders kitaplarında değerler ve değerler eğitimine yönelik örneklere daha çok yer verilebilir.

Ünite, ya da konu sonunda kitapta boş kalan yerler atasözleri ya da özlü sözlerle doldurulabilir.

Tablo 5'deki görüşler incelendiğinde yeni programdaki değerlerin öğrencilere kazandırılmasına yönelik yapılan çalışmaların (“Aziz Sancar'ın Başarısı” adlı okuma parçası vb.) yerinde olduğunu göstermektedir. Adayların "Ünite, ya da konu sonunda kitapta boş kalan yerler atasözleri ya da özlü sözlerle doldurulabilir" görüşü dikkati çeken görüşler arasındadır.

\section{Beşinci Alt Probleme İlişkin Bulgular}

Tablo 6: Öğretmen Adaylarının Görüşlerine Göre Aziz Sancar’ın Başarısı Adlı Okuma Parçasında Bulunan Değerler

\begin{tabular}{llllll}
\hline \multicolumn{6}{l}{ Okuma parçasında bulunan değerler } \\
\hline Alçak Gönüllülük & Azmetme & Adalet & Bağlılık & Bağımsızlık & Çalışkanlık \\
\hline Dayanışma & Dostluk & Eşitlik & Emek & Empati & İdealist \\
\hline Helal kazanma & Kararlılık & Güven & Minnettarlık & Mütevazılık & Özlem \\
\hline Özgürlük & Özgüven & Sabır & Saygı & Sevgi & Sorumluluk \\
\hline Sosyalleşme & Vatan borcu & Vatanseverlik & Yardımseverlik & & \\
\hline
\end{tabular}


Öğretmen adaylarının görüşlerine göre okuma parçasında bulunan değerler (Tablo 6) öğretim programında (Şekil 1) öğrencilere kazandırılması hedeflenen değerlerin olduğu görülebilir.

\section{Altıncı Alt Probleme İlişkin Bulgular}

Tablo 7: Öğretmen Adaylarına Göre “Aziz Sancar'ın Başarısı” Adlı Okuma Parçası ile Kazandırılmak İstenilen Değerler ve Değerlerin Eğitimiyle İlişkili İfadeler

\begin{tabular}{|c|c|}
\hline Değerlerin Eğitimiyle İlişkili İfadeler & Kazandırılması Hedeflenen Değerler \\
\hline $\begin{array}{l}\text { Mardin'in Savur ilçesinden Amerika'ya alın } \\
\text { teriyle gittiği, }\end{array}$ & Helal kazanç, azmetme, sabır, çalışkanlık \\
\hline $\begin{array}{l}\text { Bulunduğu mertebeye maddi imkânlarla gel- } \\
\text { mediği aksine çok çalışarak ulaştığ1, }\end{array}$ & Çalışkanlık, azmetme, kararlılık, sabır \\
\hline $\begin{array}{l}\text { Amerika şartlarında zorlandığı için sıkıntılar } \\
\text { çektiği, }\end{array}$ & Azmetme, sabir, sorumluluk \\
\hline $\begin{array}{l}\text { Amerika'da okuyan Türk öğrenciler için Türk } \\
\text { evi açması, }\end{array}$ & $\begin{array}{l}\text { Yardımseverlik, dayanışma, vatanseverlik, millet } \\
\text { sevgisi, vatan borcu, empati }\end{array}$ \\
\hline $\begin{array}{l}\text { Mardin'in Savur ilçesindeki lise birincisine her } \\
\text { y1l } 7500 \text { dolar vermesi, }\end{array}$ & $\begin{array}{l}\text { Yardımseverlik, dayanışma, vatanseverlik, millet } \\
\text { sevgisi, vatan borcu }\end{array}$ \\
\hline $\begin{array}{l}\text { Türk evini yurt ve kültür merkezi olarak kul- } \\
\text { lanılması, }\end{array}$ & Vatanseverlik, millet sevgisi, özlem duyma \\
\hline Amerikalılara Türkçe eğitim kursu açması, & Vatanseverlik, sosyalleşme \\
\hline $\begin{array}{l}\text { Başarı için çalışmak gerektiği ve bunun vatan } \\
\text { borcu olduğu, }\end{array}$ & $\begin{array}{l}\text { Çalışkanlık, sorumluluk, vatanseverlik, vatan } \\
\text { borcu }\end{array}$ \\
\hline Özgüveni cumhuriyetin verdiği, & Özgüven, özgürlük, bağımsızlık, \\
\hline Hocalarının çok idealist olduğu, & İdealistlik \\
\hline Türk milleti isterse her şeyi yapabileceği, & Özgüven \\
\hline $\begin{array}{l}\text { Üstün olmanın genetik olmadığı çok çalışmak } \\
\text { gerektiği, }\end{array}$ & Çalışkanlık, üstünlük, emek \\
\hline Bütün insanların eşit olduğu, & Adalet, eşitlik \\
\hline $\begin{array}{l}\text { Bireyleri birbirinden ayıranın zekâ olmadığı, } \\
\text { aksine emek olduğu, }\end{array}$ & Çalışkanlık, emek, azim, azmetmek \\
\hline $\begin{array}{l}\text { Şan ve şöhret için çalışmadığı vatanına milletine } \\
\text { karşı borçlu olduğu için çalıştığı, }\end{array}$ & $\begin{array}{l}\text { Mütevazılık, minnettarlık, vatanseverlik, Çalışkan- } \\
\text { lık, sorumluluk, vatan borcu }\end{array}$ \\
\hline Türk evini açması, & $\begin{array}{l}\text { Vatanseverlik, millet sevgisi, sorumluluk, vatan } \\
\text { borcu }\end{array}$ \\
\hline $\begin{array}{l}\text { Aldığı ödülün kendisi değil onu ödüle götüren } \\
\text { yol ve keşif olduğu, }\end{array}$ & $\begin{array}{l}\text { Mütevazilik, vatanseverlik, Çalışkanlık, sorumlu- } \\
\text { luk, alçakgönüllülük, minnettarlık }\end{array}$ \\
\hline $\begin{array}{l}\text { Ödüle giden yolun Atatürk'ün yapmış olduğu } \\
\text { eğitim inkılabı olduğu, }\end{array}$ & Sayg1, sevgi, minnettarlık, rol model alma \\
\hline Aldığı ödülü anıtkabir vermesi & Vatan borcu ödeme, vefa, sayg1, sevgi \\
\hline
\end{tabular}

Öğretmen adayları Şekil 2'deki okuma parçasının hemen hemen her cümlesinde öğrencilere kazandırılmak istenilen değerlerin eğitimiyle ilişkili ifadelerin bulunduğunu belirtmişlerdir (Tablo 7). Öğretmen adaylarının Tablo 7'deki görüşlerine göre en fazla dikkat çeken değerlerin vatanseverlik, yardımseverlik, çalışkanlık olduğu tespit edilmiştir. Adayların hepsi Aziz Sancar'ın orta gelirli 
sekiz çocuklu bir ailede köyde çiftçilikle yaşamını sürdürdüklerini, başarı için sosyoekonomik yapının önemli olmadığını ve çok çalışmak gerektiğini vurgulayarak Aziz Sancar'ın "Ne yaparsanız, iyi yapmaya çalışın, çalışmadan olmaz. Öğrenciyken günde 18 saat çalışırdım. Gecelerimi laboratuvarlarda geçirmişimdir. Çalı̧̧maktan başka çare yoktur.” sözlerine atıfta bulunmuşlardır.

\section{Tartışma, Sonuç ve Öneriler}

Yeni kimya öğretim programına Değerlerimiz' in (Şekil 1) eklenmesindeki gerekçeler incelendiğinde öğretmen adaylarının görüşleriyle paralellik gösterdiği söylenebilir. Çünkü öğretim programında öğrencilere kazandırılması istenilen değerler sırasıyla adalet, dostluk, öz denetim, sabır, saygı, sevgi, sorumluluk, vatanseverlik ve yardımseverliktir. Bu açıdan bakıldığında öğretmen adayları kök değerlerinin hangileri olduğunun bilincinde oldukları söylenebilir. Adaylarının okuma parçasını değerler ve değerler eğitimi açısından yorumlamaları onların değerlere karşı farkındalıklarının olduğunu düşündürmektedir.

Öğretmen adaylarının hepsi öğretim programlarının odağına değerler ve değerler eğitiminin yerleştirilmesindeki nedenlerden birinin yakın zamanda gerçekleşen 15 Temmuz kalkışma hareketinin etkisinin olduğunu düşünmekteler. Onların bu düşüncesi, ülke gerçeklerinin öğretim programlarını etkilediğini ya da öğretim programları hazırlanırken ülke gerçeklerinin dikkate alındığını düşündürmektedir. Bu düşünceyi Üce ve Şahin'in (2001), yapmış olduğu araştırmanın sonuçları desteklemektedir. Çünkü araştırmacılar öğretmen adaylarının görüşlerine dayanarak ortaöğretim kimya öğretim programı hazırlanırken ülke gerçekleri, öğrenci düzeyleri ve toplumun ideallerinin göz önünde bulundurması gerektiğini belirtmişlerdir. Öğretim programlarına değerlerin eklenme nedenlerinde en dikkati çeken bir diğer görüş değerlerin sadece sosyal içerikli derslerde değil tüm derslerde verilmesi gerektiğini belirtmeleridir. Bu görüşle öğretmen adayları değerlerin birkaç ders kapsamında öğrencilere kazandırılmasının yeterli olmayacağını, ailede başlayan değerler eğitiminin okuldaki eğitimle devamlılı̆̆ının ve kalıcılığının sağlanması gerektiğini vurgulamışlardır. $\mathrm{Bu}$ durum onların öğrencilere tüm derslerin kazanımları verilirken değerlerin de kazandırılabileceğinin farkında oldukları söylenebilir. Öğretmen adaylar1nın görüssleri arasında "Öğrencilere değerleri kazandırmak için öncelikle öğretmenlerin bu konuda bilinçlendirilmesi gerekir. Bunun için hizmet içi eğitimler düzenlenebilir.", "Lisans programlarında değerler ve değerler ĕgitimine 
yönelik kredisiz zorunlu ders olabilir." görüşlerinin olması onların değerlerin eğitiminde öğretmenlerin görev ve sorumluluklarının fazla olduğunun farkında oldukları ve bu konuda hizmet öncesinde donanımlı yetişmek istedikleri söylenebilir. Aladağ’a (2012) göre değerlerin öğrencilere kazandırılmasında okullara ve öğretmenlere önemli görevler düşmektedir. Berkant, Efendioğlu ve Sürmeli (2014), yapmış oldukları araştırmada öğretmenlerin öz eleştiri yaparak değerler eğitimine yeterince özen göstermediklerini, ama sorunun kaynağı da olmadıklarını belirttiklerini ve değerler eğitimimin istenilen düzeyde okullarda verilmesi için programların destekleyici olması gerektiğini vurgulamışlardır. Araştırmanın katılımcıları ders sırasında yeri geldiğinde öğretmenlerin konuyla ilişkili değerlerden söz etmesi gerektiğini, Atatürk'ün hayatına daha çok yer verilmesiyle değerlerin kazandırılabileceğini, ünite ya da konu sonlarında kitapta boş kalan yerlerin atasözleri ya da özlü sözlerle doldurulabileceğine yönelik görüşlerin bulunması değerler ve değerler eğitiminin mutlaka verilmesi gerektiğini düşündürmektedir. Gerçekte atasözleri ve özlü sözler öğrencilere değerlerin kazand1rılmasında kullanılan önemli araçlardan biridir. Nitekim Mindivanlı, Küçük ve Aktaş (2012), atasözleri ve deyimlerin değerlerin eğitiminde kullanılabileceğini belirtmişlerdir. Karaer ve Avcı (2018), kimyanın atasözleri ile ilişkilendirilebileceğini, ortaöğretim ders kitabında yer alması gerektiğini, değerlerin öğretimine katkıda bulunacağını örneklerle açıklamışlardır. Örneğin araştırmacılar kuvvetli asit ve zayıf asit karışımının kuvvetli bir bazla titre edilmesini veya kuvvetli baz ve zayıf baz karışımının kuvvetli bir asitle titre edilmesini "Büyük dururken kü̧̈üğe söz düşmez." atasözü ile ilişkilendirerek değerlerimizden büyüklere saygının kazandırılabileceğini belirtmiş ve ders kitabına konulmasını önermişlerdir.

Katılımcıların “Aziz Sancar'ın Başarısı" adlı okuma parçasının ders kitabına konulmasının iyi olduğuna yönelik görüşlerini Tulunay-Ateş'in (2017) yapmış olduğu araştırmanın sonuçları desteklemektedir. Çünkü araştırmacı, değerler eğitimine yönelik yapılan uygulamalarının öğrencilere olumlu davranışların kazandırılmasında etkili olduğunu açıklamıştır. Katılımcıların ders kitabı aracılığı ile değerlerin kazandırılmasında Aziz Sancar vb. önemli şahsiyetlerle ilgili okuma parçalarının bulunmasının yanında değerlerin öğretiminde kullanılan diğer araçlardan da yararlanılabilir. Çünkü katılımcılar ders kitabında atasözü ya da özlü sözlerden yararlanabileceğini belirterek ünite ya da konuların sonunda boş kalan yerlerin atasözü veya özlü sözlerle doldurabileceğini önermeleri onların ünite ya da konuların sayfa başında başlamasını istediklerini ve kimyanın ya- 
nında değerlerin kazandırılmasında ders kitabı, öğretmen vb. faktörlerin etkili olduğunun bilincinde olduklarını düşündürmektedir. Aynı zamanda bu durum değerler eğitiminin sadece ailede olmadığını okul çağının her düzeyinde olması gerektiğinin farkında olduklarının da göstergesi olabilir.

Kimya öğretim programı aracıllğı ile değerlerin öğrencilere kazandırılmasında Aziz Sancar vb. önemli şahsiyetlere ders kitabında daha çok yer verilerek programdaki değerlerin kazandırılması sağlanabileceği gibi öğrencileri bilim insanı olmaya da özendirilebilir. Çünkü Aziz Sancar Nobel ödülü almış dünya çapında tanınan bir bilim insanıdır. "Aziz Sancar'ın Başarısı” adlı okuma parçasının 9. Sınıftaki Kimya Ders Kitabına eklenmesinin değerlerin eğitimi için iyi bir araç olduğu, sadece öğrenciler değil öğretmenler açısından da önemli olduğu görülebilir. Çünkü parçada Aziz Sancar'la yapılan bir röportajda çok idealist hocalarının olduğunu belirtmesi sadece öğrencilere değerleri kazandırmakla kalmayıp aynı zamanda öğretmenlere ideal öğretmenin niteliklerini öğrenip benimsemelerine yönelik mesajlar da verdiği söylenebilir. Ayrıca Aziz Sancar bu sözüyle öğretmenlere çok büyük görev ve sorumlulukların olduğunu, davranışlarıyla, konuşmalarıyla öğrencilerin dikkatini çeken, onlara rol model olan kişilerin başında geldiğini hissettirmek ve hatırlatmak istediğini düşündürmektedir.

Parçada geçen alçak gönüllülük, çalışkanlık, yardımseverlik, emek, inatçılık, sabır, kararlılık, vatanseverlik, vatan borcu, minnettarlık, dayanışma, sorumluluk, özgüven, idealist, özgürlük, kendine güven, üstünlük, eşitlik, adalet, mütevazılık, sayg1, bağlılık, bağımsızlık, sosyalleşme değerleri (Tablo 6) programda olan değerlerle örtüşmektedir. Bu durum öğrencilere kazandırılmak istenilen değerlerin ve eğitiminin okuma parçası aracıllğı ile amaç ve hedeflerine ulaşabilir olduğunun göstergesi sayılabilir. Ancak bu durum öğretmenlerden beklenen hassasiyet gerçekleşirse olabileceğini aksi takdirde sıradan bir okuma parçası olarak ders kitabında kalacağını düşündürmektedir. Öğretmen adaylarının değerlerin eğitimiyle ilişkili olduğunu düşündükleri parçadaki ifadeler (Tablo 7) incelendiğinde değerlerin hemen hemen okuma parçasında olduğu görülebilir. Örneğin, öğretmen adaylarının başarıda sosyoekonomik yapının önemli olmadığını aksine başarı için çok çalışmak gerektiğini vurgulayarak Aziz Sancar'ın röportajdaki sözüne atıfta bulunmaları onların okuma parçası aracılığı ile değer olarak çalışkanlığın kazandırılması hedeflendiğini ve çalışkanlığın insan hayatında önemli bir yer tuttuğunun bilincinde olduklarının göstergesi olarak görülebilir. Ayrıca bu araştırma öğretmen adaylarının ders kitabındaki okuma parçalarına karşı ilgilerini artırdığını, bu konuda kendilerini geliştirdiklerini, öğretmen 
olduklarında öğrencilerine kök değerlerini neden, nasıl vermeleri ve toplumun arzu ettiği bireyleri kök değerlerine göre nasıl yetiştirmeleri gerektiğine yönelik gerekli bilgi ve deneyimi lisans eğitimlerinde kazandıkları söylenebilir.

$\mathrm{Bu}$ sonuçlardan hareketle aşağıdaki öneriler verilebilir.

- Öğrencilere derslerin kazanımları verilirken değerlerin de kazandırılması,

- Atatürk'ün hayatına ve Aziz Sancar vb. önemli tanınmış şahsiyetlere daha çok yer verilmesi,

- Atasözleri ya da özlü sözler vb. değerlerin eğitiminde kullanılan diğer araçlardan da yararlanılması,

- Değerler eğitimi konusunda öğretmenlerin bilinçlendirilmesi için hizmet içi eğitimlerin düzenlenmesi,

- Öğretmenlere değerler eğitimine yönelik yapılacak hizmet içi eğitimlerde öğrencilerde davranış değişikliği olacak şekilde programın hazırlanması,

- Değerler ve değerler eğitimi kredili/kredisiz zorunlu ders olarak eğitim fakültelerinin lisans programlarında okutulması için gerekli alt yapı çalışmalarının yapılması önerilmektedir.

\section{Kaynakça}

Aladağ, S. (2012). İlköğretim sosyal bilgiler öğretiminde değer eğitimi yaklaşımlarının öğrencilerin sorumluluk değerini bilişsel düzeyde kazanmalarına etkisi. Türkiye Sosyal Araştırmalar Dergisi, 16(1), 123-146.

Berkant, H. G. Efendioğlu, A. ve Sürmeli, Z. (2014). Değerler eğitimine yönelik öğretmen görüşlerinin incelenmesi, Turkish Studies-International Periodical for the Languages, Literature and History of Turkish or Turkic, 9(5), 427-440.

Balcı, F. A. ve Yanpar Yelken, T. (2013). İlköğretim sosyal bilgiler programında yer alan değerler ve değerler eğitimi uygulamaları konusunda öğretmen görüşleri. Ahi Evran Üniversitesi Ĕgitim Fakültesi Dergisi, 14(1), 193-213.

Başkale, H. (2016). Nitel araştırmalarda geçerlilik, güvenirlilik ve örneklem büyüklüğünün belirlenmesi. Dokuz Eylül Üniversitesi Hemşirelik Fakültesi Elektronik Dergisi (DEUHFED), 9(1),23-28.

Cihan, N. (2014). Okullarda değerler eğitimi ve Türkiye'deki uygulamaya bir bakış. Turkish Studies, International Periodical for the Languages and History of Turkish or Turkic, 9(2), 429-436.

Creswell, J.W. (2016). Research design qualitative, quantitative, and mixed methods approach. Çev. Selçuk Beşir Demir, Araştırma deseni nitel ve karma yöntem yaklaşımları. Ankara: Eğiten Kitap. 
Coşkun, Y. D. (2016-2017). Öğretim programları arka plan raporu. Eğitim Reformu Girişimi, 1-23.

Çelikkaya, T. Kürümlüoğlu, M. (2018). Yeni sosyal bilgiler programında 4. ve 5. sınıfta kazandırılması hedeflenen değerlerle ilişkin kazanımların içeriğe yansıması. Değerler Ĕ̆itimi Dergisi, 16(36), 7-38.

Demirel, M. (2009). A review of elementary education curricula in Turkey: values and values education. World Applied Sciences Journal, 7, 670-678.

Dilmaç, B ve Şimşir, Z. (2016). Okullarda değerler eğitimi. https://www.researchgate.net. publication /312057443_okullarda_değerler_eğitimi, Erişim: 27 Ocak 2019.

Durmuş, A. (2017). Değerler eğitimi ve örtük müfredat. www.hurriyet.com.tr/egitim/ ogrencilere-10-maddede-degerler-egitimi-40693703, Erişim: 11 Ağustos 2018.

Faiz, M. \& Yazıc1, K. (2018). Social studies teacher candidates 'views on the use of historical heroes in values education. International of Eurasia Social Sciences, 9(33), 1897-1918.

Genç, S. Z. ve Eryaman. M. Y. (2007). Değişen değerler ve yeni eğitim paradigmas1. Afyon Kocatepe Üniversitesi Sosyal Bilimler Dergisi, 9(1), 89-102.

Gentles, S. J., Charles, C., Ploeg, J. \& McKibben, K. A. (2015). Sampling in qualitative research: Insights from an overview of methods literature. The Qualitative Report, 20(11), 1772-1789.

Güntut, M., Güneş, P. ve Çetin, S. (2018). 3. Ünite: Kimyasal türler arası etkileşimler. Tunalı Akar, S. (Ed.), Ortaöğretim Kimya 9. Sinıf Ders Kitabı (s. 96104). Ankara: Millî Eğitim Bakanlığı

Halstead, M. \& Taylor, M. J. (2005). Values education and values in edition. A Guide to the issues, London. Association of Teachers and Lecturers, 225. e-book.

Harsh, S. (2011). Purposeful sampling in qualitative research synthesis. Qualitative Research Journal, 11(2), 63-75.

Johnson, B. \& Christensen, L. (2014). Educational research. Çev. Selçuk Beşir Demir, Eğitim araştırmaları nitel, nicel ve karma yaklaşımları, (4. Baskı). Ankara: Eğiten Kitap

Karaer, H. ve Avcı, E. (2018). Kimya öğretiminde atasözlerinin kullanılmasına yönelik öğretmen adaylarının görüşleri. Language Teaching and Educational Research (LATER), 1(2), 139-162.

Khan, S. N. (2014). Qualitative research method-phenomenology. Asian Social Science, 10(21), 298-310.

Kızıçelik, S. ve Erjem, Y. (1994). Açıklamalı sosyoloji terimler sözlüğü. Ankara: Atilla Kitapevi 
Koç, S. ve Çelik, A. (2017). Ortaokullarda örtük olarak verilen değerler konusunda lisansüstü öğrencilerinin görüşleri. Gazi Üniversitesi Gazi Eğitim Fakültesi Dergisi GEFAD, 37(2), 711-735.

Koçak, A. ve Arun, Ö. (2006). İçerik analizi çalışmalarında örneklem sorunu. Selçuk Iletişim, 4(3): 21-28

MEB. (2017). Müfredatta yenilenme ve değişiklik çalışmalarımız üzerine https:// ttkb.meb.tr/ meb_iys.../2017.../18160003_basin_acıklamasi-program.pdf Erişim: 10 Ağustos 2018.

MEB. (2018). Müfredatta yenilenme ve değişiklik çalışmalarımız üzerine https:// ttkb.meb.tr/ meb_iys.../2017.../18160003_basin_acıklamasi-program.pdf erişim tarihi 10.08.2018

Mindivanlı, E., Küçük, B. \& Aktaş, E. (2012). Sosyal bilgiler dersinde değerlerin aktarımında atasözleri ve deyimlerin kullanımı. Ĕgitim ve Ögretim Araştırmalart Dergisi, 1(3), 93-101.

Onat-Kocabıyık, O. (2016). Olgu bilim ve gömülü kuram: bazı özellikler açısından karşılaştırma. Trakya Üniversitesi Eğitim Fakültesi Dergisi, 6(1), 55-66.

Özcan, Y. S. (2017). Değerler eğitimi nasıl olmalı. www.trtcocuk.net.tr>ebeveyn erişim tarihi 11.08.2018.

Padilla-Diaz, M. (2015). Phenomenology in educational qualitative research: Philosophy as science or philosophical science. International Journal of Educational Excellence, 1(2), 101-110.

Patton, M. Q. (2015). Qualitative research \& evaluation methods: integration theory and practice (4th ed). London and Thousand Oaks, CA: Sage

Rose, S. Spinks, N. \& Canhoto, A.I. (2015). Management research the principles. (1th ed), Routledge, Taylor \& Francis group, London (documents. Routledge-interactive. s3. amazonaws.com/.../Chap erişim tarihi 09.08.2018

Taylor, M. J. (2000). Values education: issues and challenges in policy and practice in education, Edited by Leiccester, M., Modgil, C. and Modgil, S. Vol. 2. London: Falmer.

Tedmem (2017). Öğretim programı taslaklarında değerler eğitim. https://tedmen. org > Mem Notları > Görüş Erişim tarihi: 10 Ağustos 2018.

Thornberg, R. \& Oğuz, E. (2013). Teacher's views on values education: a qualitative study in Sweden And Turkey. International of Educational Research, 59(1),49-56.

Thronberg, R. (2008a). The lack of professional knowledge in values education. Teaching and Teacher Education, 24, 1791-1798.

Thronberg, R. (2008b). Values education as the daily fostering of schools' rules. Research in education, 80, 52-62. 
Tulunay Ateş, Ö. (2017). Türkiye'de değerler eğitimi uygulamalarının öğrencilere kazandırılması istenen önemli özellikler üzerindeki etkisi. Değerler Ĕgitimi Dergisi, 15(34), 41-60.

Üce, M. Ve Şahin, M. (2001). Kimya öğretmen adaylarının ortaöğretim kimya eğitimi hakkındaki düşünceleri. Marmara Üniversitesi Eğitim Fakültesi Eğitim Bilimleri Dergisi, 13, 165-174.

Ünal, F. (2011). Öğretmenlerin öğrencilerine kazandırılmak istedikleri değerlere yönelik bir inceleme. Eğitim ve İnsani Bilimler Dergisi: Teori ve Uygulama, 2(4), 3-24.

Yazıc1, S. ve Aslan, M. (2011). Değerler eğitiminde kahramanlardan yararlanma: sosyal bilgiler ders kitapları ile öğretmen adaylarının kahraman tercihlerinin karşılaştırılması üzerine bir çalışma. Kuram ve Uygulamada Eğitim Bilimleri, 11(4), 2173-2188.

Yıldırım, A., Şimşek, H. (2013). Sosyal bilimlerde bilimsel araştırma yöntemleri. (9. Baskı). Ankara: Seçkin Yayıncılık.

Yüksel, P. \& Yıldırım, S. (2015). Theoretical frameworks, methods, and procedures for conducting phenomenological studies in educational settings. Turkish Online Journal of Qualitative Inquiry, 6(1), 1-10.

Zhang, Y. \& Wildemuth, B. M. (2009) Qualitative analysis of content. In Wildemuth, B. M. (Ed.), Applications of social research methods to questions in information and library science. Westport: Libraries Unlimited, pp. 308-319.

Weber, R. P. (1989). Basic content analysis. London: Sage 
Extended Abstract

\section{Opinions of Chemistry Teacher Candidates about the Values and Values Education in the Reading Piece Named Aziz Sancar's Success}

Hatice KARAER, Corresponding Author. Assistant Professor.

Ondokuz Mayıs University, Faculty of Education.

E-mail: hkaraer@omu.edu.tr

ORCID: 0000-0001-7745-9587

Fergan KARAER, Assistant Professor.

Ondokuz Mayıs University, Faculty of Education.

E-mail: fkaraer@omu.edu.tr

ORCID: 0000-0003-3781-2128

\section{Introduction}

In today's education system, it is aimed that each student will be trained to show their behaviour by taking appropriate moral characteristics, students are expected to be educated not only to be academically successfully individuals but also as individuals who know their values and show them in their behaviours. For this purpose, the Ministry of National Education has placed its focus on all curricula by adding basic values. When new curricula and previous curriculums are compared, there are some differences in terms of content. The main difference is placing national and spiritual values at the centre of new programs while gaining skills was at the centre of previous curriculums. A statement referring to national education's aim in the Basic Law of National Education that says ;"ed- 
ucating individuals who adopt, protect and develop the national, moral, human, spiritual and cultural values of the Turkish nation' shows that creating common values in all curricula is inevitable. Values are important not only in the field of education but also in daily activities. Because values education is the accumulation of the efforts that help students develop knowledge, skills and abilities that would help them in making decisions and reasonable choices.

\section{Purpose and Importance of Research}

The aim of this study is to determine the opinions of chemistry teacher candidates about the values and values education in the reading piece named "Aziz Sancar's Success" in the $9^{\text {th }}$ Grade Chemistry Textbook. It is thought that reading passages belonging to important figures will contribute to the field in terms of showing that how they could be regarded as a good tool for values education. At the same time, the fact that the chemistry teacher candidates show the knowledge, skills and experience about how to analyse a reading part in the textbook in terms of values and values education will contribute to the future research to be done because it is the first research which examines a reading passage titled Aziz Sancar's Success in terms of values and vales education.

\section{Problem of Research}

What are the opinions of the teacher candidates on the values and values education in Aziz Sancar's Success story in the $9^{\text {th }}$ Grade Chemistry Textbook?

\section{Method}

\section{Pattern of Research}

Phenomenology (Phenomenon-science) method is used in the research. Because the participants of this study were asked to analyse Aziz Sancar's Success reading passage in terms of values and values education, the Phenomenology pattern was preferred because it aims to investigate the participants' experience with fact and events, and what kind of perception they form and structure.

\section{Participants of the Research}

Since the Phenomenology pattern was used in the research, criterion sampling was preferred because it was easy to apply for purposeful sampling types, and 
the results are concluded in a short time and it allows the researcher to determine the criterion. Participants of the research are eight chemistry teacher candidates who are registered and voluntarily in the Secondary School Chemistry Curriculum Course, which is taught as an elective course in the 4-year chemistry teaching undergraduate program of public university in Turkey. All of the teacher candidates stated that they chose the profession of teaching willingly and were content with that.

\section{Data Collection Tools}

The data of the research was obtained through a form of the opinion containing three open-ended questions, related to the reading passage titled Aziz Sancar's Success in the $9^{\text {th }}$ Grade Chemistry Textbook and from the Secondary Chemistry Teaching program. In addition, data was collected from the qualitative observations made by the researcher during their study of the values and value education.

\section{Data Analysis}

In the analysis of the data, content analysis was used. In the analysis of the opinions of teacher candidates, themes were determined by taking into account the sub problems. The determined themes were shown to the expert instructors and corrections were made in line with their opinions and suggestions and six themes were created. Created themes respectively;

"values in the program", "reason for adding values to the program", "the reason for gaining value", the values in the reading passage Aziz Sancar's Success" and "values education through the success of Aziz Sancar".

\section{Validity and Reliability}

In this research, the detailed explanation of the information about the teacher candidates is given under the title in the Participants of the Research part. Why and how the data collection tools are used, and the reading piece named "Aziz Sancar's Success" is given in detail under the title of data collection. Thus, the internal validity of the research is ensured. The external validity of research is why the criterion is selected by criterion sampling, the criterion sampling decision is taken, what is collected is selected in the data collection and the necessary information about how the analysis is done is explained in detail in the rel- 
evant sections. In order to determine whether the themes created by the opinions of the teacher candidates are appropriate, the opinions of the lectures and their opinions and suggestions are arranged and the internal reliability of the research is ensured. According to the results of content analysis, it is possible to say that the external security is performed in order to compare the research results with the expert opinion and to show the role in the research of the researchers.

\section{Findings}

It is found that there is a similarity between the values found in the chemistry curriculum and the values intended to be given to the students in curriculum. In the opinion of the teacher candidates, it was found that the most noteworthy views were about the 15 July movement and the students were asked to show national unity and solidarity. It was found that opinions acquired in the family should be given at all different stages of school education. Results also show that reading passages in the new programme like the one titled: "Aziz Sancar's Success" were appropriate in helping students acquiring values. Another noteworthy opinion of the candidate is that at the end of each chapter or subject, the empty spaces in the book can be filled by proverbs or quintessential words.

\section{Discussion, Conclusion and Recommendations}

The values that are expected to be given to the students in curriculum are justice, friendship, self-control, patience, respect, love, responsibility, patriotism and helpfulness. In this respect, it can be said that teacher candidates are aware of the root values. The interpretation of the reading part in terms of values and values education suggests that candidates do have awareness about values. The teacher candidates emphasized that it would not be enough to give the values to the students within the scope of a few courses and that should be given in all courses in all stages of school education. It can be said that it is good to put the reading piece named Aziz Sancar's success in textbook of the teacher candidates. In order to provide the students with the values through the curriculum of chemistry, Aziz Sancar and other important figures can be promoted in textbook and the values in the program can be acquired, thus students can be encouraged to become scientists. Aziz Sancar is a world-renowned scientist, who has been awarded the Nobel Peace Prize. It can be seen that including the reading piece named Aziz Sancar's success to the chemistry textbook in the $9^{\text {th }}$ Grade is a good tool for the education of values, not only for the students but also for the 
teachers. Because in the reading passage Sancar stated in his interview that he had very idealistic teachers. He is not only trying to transmitting values to the students, but also giving the teachers a messages about learning and adopting the qualities of an ideal teacher. This situation can be considered as an indication that the vales and its education can reach goals and targets. However; this is only possible if the teachers are able to show the expected sensitivity, otherwise it will remain in the textbook as an ordinary piece. Examining the expressions of teacher candidates about to the education of values, it can be seen that the values referred to are almost in the reading part. For example, they highlited the fact that for achieving success, hard work is more important than the socio-economic factors, which parallels the information in the reading passage about Aziz Sancar; which says that he was born in a village to a farmer family of middle income with eight children. This can be seen as an indicator of of the teacher candidates' awareness in promoting the value of hard working and its importance in the human life. In addition, we can say that this research has increased the prospective teachers' interest in reading textbook, and willingness to improve themselves in this subject, and when they became teachers, they will know why and how they can give the basic values to their students. We that prospective teachers have gained the necessary knowledge and experience in their undergraduate education about how they should raise individuals according to the basic and desired values of the society.

Based on the results, the following recommendations can be given.

- Important prominent figures (Atatürk's life and Aziz Sancar's successes etc. ) can be given more places in curriculum and textbook,

- To benefit from other tools (Proverbs etc. ) used in values and values education.

- In-service trainings can be organized to raise awareness of teachers about values education,

- During in-service training, preparing the content of the program related to value teaching in a way to accommodate the change in the behavior of the students.

- In addition, values and values education should be included in all undergraduate programs as compulsory courses. 
